\title{
Financial Perspective of the Balanced Scorecard: Strategies for Profitability
}

\section{By Craig A. Payne and Pete Talbott}

${ }^{6} \mathrm{D}$ rofitability measures the extent to which a business generates profits from the use of land, labor, management, and capital"1 (p. III-2) and its importance in ranching cannot be overemphasized. Profitability promotes owner satisfaction and it is essential for sustainability of the business. It also creates financial success, which supports not only the business, but also land stewardship and quality of life for those involved. It is not surprising then, that we commonly find a reference to profitability or profit in the vision statement of a business.

Assuming this is also part of the vision of the ranch for which we are creating the Balanced Scorecard, the financial perspective should contain strategies that increase profit and techniques for monitoring profitability in order to link the perspective to the vision. The following are examples of strategies and techniques the authors feel best accomplish this. Also included in the discussion are metrics that represent suggested ways of accomplishing each strategy (Table 1).

\section{Strategy 1: Establish Profit/Cost Centers}

In order for a ranch to thoroughly analyze its financial performance, it should organize its accounting system and management around profit and cost centers. A profit center is an area of the operation that receives income from off-ranch sources and the cost center is an area of the operation that only incurs costs and does not have a product for sale. The benefit of using profit and cost centers is the ranch can determine which segment of the operation generates the most profit and cash to pay for all the overheads (cost centers) that impact the different production units (profit centers).

This article has been peer reviewed.
Table 1. Example strategies and corresponding metrics for the financial perspective of the Balanced Scorecard for a ranch

1. Establish profit/cost centers

2. Establish a chart of accounts for management

3. Manage costs

- Budgeting

- Break-even analysis

- Cash flow projection

4. Manage/monitor debt

- Net present value (NPV) or internal rate of return (IRR)

- Debt-to-asset ratio

- Current ratio

5. Financial efficiency

- Return on assets

- Operating expense ratio

6. Measuring and monitoring profitability

- Return on assets

- Return on equity

- Net ranch income

- Trend analysis

- Benchmarking

To better understand the concept of profit and cost centers, it is helpful to use an example of a cow-calf ranch that also runs stockers. If the ranch sells calves (plus cull breeding 
animals) and stockers, then it has two profit centers, one for cows and one for stockers. Cost centers in the business might be equipment, general and administrative, and crops grown for the sole purpose of feeding (not for sale).

Profit centers include all the income associated with that center and all the costs that can be charged directly to that center. In the previous example, income from calf sales is included in the cow profit center. The cow profit center will also contain costs that can be directly expensed to it. Examples of this would be vaccine, supplements, and even the fuel that is used in the pickup specifically for the cows, not the stockers.

Cost centers include all expenses that are not directly associated with a specific profit center. Using an equipment cost center as an example, the cost of tires for the pickup would be expensed here because the tires will be used for all ranch activities, not just cows or stockers. The general and administrative cost center would take all the expenses that do not fall into one of the other cost centers. Examples of this would be accounting fees, insurance and supplies not easily allocated to a profit center.

During year-end preparation of the books, a percentage of each cost center is allocated to a profit center. If it is determined that $70 \%$ of the equipment expenses should be charged to cows and 30\% to stockers, then that allocation would be made. This is done with general and administration and any other cost centers, with all costs being allocated to a profit center(s).

\section{Strategy 2: Establish a Chart of Accounts for Management}

A complete list of how financial resources are to be handled in the business is essential and it is critical that it be done based on the needs of management and not for tax purposes. Examples of accounts would be: Assets, Liabilities, Owner's Equity, Revenues, and Expenses. For the Balanced Scorecard, the focus is on revenues and expenses. The chart of accounts should reflect how the business wants to track the financial activity of the established profit and cost centers.

Revenue accounts would list all the various income sources or classifications that are traceable when products are sold. Expense accounts would list all those areas of expenditures that are important to manage and analyze as it relates to either direct expenses to a profit center or a general expense for a cost (or support) center.

\section{Strategy 3: Manage Costs}

In its most basic form, profit is comprised of two components: revenues and costs (Profit $=$ Revenues - Costs). This means that profits can be increased by generating more revenue, by managing costs, or by using a combination of both. However, because ranching is typically a commodity business, it is generally easier to manage costs than it is to increase revenues. Therefore, managing costs is usually the preferred strategy. Using the budgeting process, performing break-even analysis, and managing cash flow are some effective ways of managing costs.

\section{Budgeting}

The budgeting process is the foundation of all business planning and it anticipates the financial outcome of the ranching operation by using probable expenditures and income. There are 2 distinct types of budget processes. One is historicaland the second is zero-based. Historical-based budgeting is the simplest as it takes the costs and incomes from the previous year and with a few minor adjustments becomes the next year's budget.

The preference of the authors is for zero-based with a few historical exceptions. By using zero-based budgeting, each line item on the budget begins with zero and the question(s) are asked, "What is really needed for the account?" By going through this process, all dollars must be accounted for and it's not just assumed that the same amount will be spent as last year.

Once the budget is prepared, monthly, quarterly, and annual comparisons to the actual expense or income items on the budget are made and analyzed. This reveals how the business is doing compared to the original plan. If there is a large discrepancy between budgeted and actual expenses, it is then important to understand why it occurred and to consider changes that need to be made in the future.

\section{Break-even Analysis}

The break-even cost is the cost of producing a unit of product at some point in the products value chain. Knowing the cost of producing a pound of weaned calf, a stocker at sale weight, a bull (for a seedstock producer) at sale time, or a ton of hay, is of the utmost importance. Knowing the exact cost on a per unit basis of the product sold or a product produced and used within the operation is critical for success. This information is useful for profit analysis of one or multiple profit centers.

Calculating the break-even is not difficult if you keep track of your costs and units of production associated with a particular product. This is done by taking the total cost and dividing it by the number of units produced during the cost time line. Calculating the cost of production per unit allows to you compare your costs to the potential market and your potential profit.

\section{Cash Flow Projection}

Projections of cash flow for the operation are critical for planning financing needs, or during times of excess cash, planning for debt repayment or investing. Many times ranchers make purchases based on tax implications and accelerated depreciation but fail to recognize how these purchases will impact future cash flow. Ignoring such factors can result in cash shortages, which reduces the ability of the operation to meet its financial obligations.

With cash-flow planning, projections are made about the timing and amount of cash inflows and outflows, and therefore cash availability can be estimated for the coming year. 
If the plan reveals cash shortages are likely, the rancher then needs to adjust next year's expenditures or borrowings to correct the shortage.

\section{Strategy 4: Managing/Monitoring Debt}

Debt is an acceptable and necessary source of capital for most ranches but it can become a problem when it is not managed properly or not monitored. In such cases, debt can become out of control and have a significant impact on the profitability of the ranch. Managing and monitoring debt are therefore important strategies.

\section{Managing Debt}

A common way to manage debt is to make sure that the investment for which the debt is incurred will provide a return that is greater than the cost of that debt. Although this seems like an elementary concept, it is often overlooked when making investment decisions.

The two methods commonly used to make this assessment are net present value (NPV) or internal rate of return (IRR). ${ }^{2}$ To describe NPV and IRR is beyond the scope of this paper but a rancher should employ one of these methods, using outside help, when making investment decisions for the operation.

\section{Monitoring Debt}

There are several ratios that can be used to monitor debt, but the two preferred here are the debt-to-asset ratio and current ratio. Debt-to-asset is a measure of financial position and expresses the proportion of the total farm assets that is owed to creditors. ${ }^{1}$ It is calculated by dividing total liabilities by total assets and a ratio of less than $30 \%$ is considered good.

The current ratio is an indication of the extent to which current farm assets, if liquidated, would cover current farm liabilities. ${ }^{1}$ In other words, it is the ability of the farm assets that will be turned into cash within 12 months to pay for the farm liabilities that will come due in that same period of time. This ratio is calculated by dividing current assets by current liabilities; a ratio above 1.5 is desirable.

\section{Strategy 5: Financial Efficiency}

The efficient use of resources is the cornerstone of successful ranching. Too often this concept is only applied to the use of rangelands or other natural resources. It is important that all assets of an operation be used efficiently for production, purchasing, pricing, financing, marketing decisions, and for generating revenues. ${ }^{1}$

The strategy of monitoring financial efficiency is included in the financial perspective so the rancher is aware of how efficiently the operation is being run. Although there are several ratios available for examining financial efficiency, the two presented here are: return on assets and operating expense ratio.

Return on assets (ROA) is a ratio that is an inclusive measure of efficiency. ${ }^{3}$ This ratio is preferred because it not only provides insight into the efficiency at which assets are used to produce net income from operations, but it is also an indication of how effective management is at deploying capital. ${ }^{4}$

Because ROA is a general measure of efficiency, those desiring greater detail can use the operational ratios, or more specifically the operating expense ratio, which measures the amount of gross revenue used to pay operating expenses. Although there are several operational ratios, the operating expense ratio is preferred because it provides information about a portion of the business (operating expenses) over which the rancher can exert immediate control. Some of the other operational ratios, such as depreciation and interest expense ratio, are important, yet they represent past investment decisions that are difficult to alter in the short term.

\section{Strategy 6: Measuring and Monitoring Profit- ability}

Up to this point the strategies have focused on increasing profitability. However, to determine if progress is being made, there needs to be a strategy in place for measuring and monitoring profitability. To measure profitability, return on assets (ROA), return on equity (ROE), and net ranch income (NRI) are preferred; for monitoring profitability, trend analysis and benchmarking are used.

\section{Measuring Profitability}

Return on assets, which has been discussed previously, is also a proven measurement of ranch profitability. ${ }^{3}$ This ratio compares Net Ranch Income to the base value of all ranch assets and is therefore an index of the net income against the value of assets employed to accomplish the production strategies that generate gross revenue. A healthy ratio would be greater than $5 \%$; however, striving for $10 \%$ or $15 \%$ is much better.

Return on Equity is the relationship of the equity or net worth of the ranching operation to the Net Ranch Income. This ratio is very helpful in comparing the profitability of ranch operations with other owned investments or potential investments. $\mathrm{ROE}$ is also very helpful in developing a trend line for the ongoing operation from year to year. Calculating this ratio is very similar to ROA in that you divide the net ranch income by the equity or balance sheet net worth.

Net Ranch Income is the calculation that remains after subtracting all expenses, including depreciation and gain or loss on the sale of capital assets, from gross revenues of the operation. This is done before income taxes. Because this does include noncash items such as depreciation, if cash-basis accounting is used, then accrual adjustments must also be incorporated into this calculation.

\section{Monitoring Profitability}

The financial measurements used so far have only provided information about the operation at a single point in time. Although this information is important, it is more valuable if it is monitored over time. This allows for the detection of trends, which gives a better indication of the financial direc- 
tion of the operation. The two methods chosen for monitoring internal financial trends are trend analysis and benchmarking.

Trend analysis is a simple process and only requires the rancher to have 5-10 years of financial data from which information can be collected. The information, which should include all of the metrics discussed so far, is displayed graphically to show the trends that are occurring within the operation.

Trend analysis not only shows how the operation has performed in the past, but it is also an indication of the future because a trend is expected to continue in the same direction until conditions change or management intervenes. Therefore, the real benefit of trend analysis is that it allows the rancher to see unfavorable trends and make necessary adjustments before they become detrimental to the operation.

Benchmarking is a process by which the rancher does a yearly financial performance comparison of the operation with similar operations. ${ }^{5}$ By doing so, it is determined how the operation is doing when compared to the industry standards. The rancher is then aware of where the inefficiencies are in the operation and adjustments can be made to improve financial performance.

Benchmark data for ranching can be collected from management consultants, extension services, industry associations, or universities. Many of the metrics that are discussed in this paper have benchmarks to which they can be compared. Although benchmarking is an extremely valuable management tool, it needs to be remembered that it is only useful when comparing "apples to apples." In other words, the comparison should be between operations of similar size and structure and the accounting methods used should be the same. The source from which the benchmark data are collected should be able to help determine the similarity of the operations.

\section{Conclusion}

A well-constructed balanced scorecard will have all strategies working together to accomplish a vision. Because profitability is assumed to exist in the vision statement for most ranches, the financial perspective includes strategies for achieving profitability and also strategies for analyzing the operation and strategies for measuring and monitoring the progress towards profitability. Although there might be others to consider, the ones presented here represent the most important and most comprehensive set of strategies for accomplishing the vision of profitability.

It is important to remember that this financial perspective (Table 1) was created for a ranch that has profitability as part of its vision. However, not all ranches will fall into this category. Some might be satisfied with merely breaking even, whereas others might choose to be profitable but only to a certain level. In such cases, the financial perspective will likely contain different strategies and metrics that are more suitable for achieving the particular vision.

Authors are Graduate Fellow, King Ranch Institute for Ranch Management, Texas AEัM University —Kingsville, Kingsville, TX 78363-8202 (Payne); and Consultant, Land E Livestock Advisory Service LLC, 17614 Tunnel Hill Rd., Lakeview, OR 97630,ptalbott@gooselake.com (Talbott).

\section{References}

1. Farm Financial Standards Council. 1997. Financial guidelines for agricultural producers: Recommendations of the Farm Financial Standards Council. Norwalk, CT: Financial Accounting Standards Board.

2. Gitman, L. J., and J. Madura. 2001. Capital budgeting techniques: certainty and risk. In: Introduction to finance. New York, NY: Addison Wesley. p 327-359.

3. Dunn, B. H. 2002. Measuring cow-calf profitability and financial efficiency. In: Proceedings of the Beef Improvement Federation, 34th Annual Research Symposium and Annual Meeting; 10-13 July 2002; Omaha, NE: Beef Improvement Federation. 218 p.

4. Miller, A., M. Boehlje, and C. Dobbins. 2001. Key financial performance measures for farm general managers. West Lafayette, IN: Purdue University Cooperative Extension Service Publication ID-243. 5 p.

5. McGrann, J. M., F. Abelló, and D. Richardson. 2003. Farm/ranch business financial analysis decision aid. College Station, TX: Texas Agricultural Extension Service and Texas A\&M University, Department of Agricultural Economics. 88 p. 